\title{
Problem of sex ratio in cases of type I syndactyly
}

\author{
CHARLES M. WOOLF AND DIANA L. CONE
}

From the Department of Zoology, Arizona State University, Tempe, Arizona, 85281, USA

SUMMARY Fifty pedigrees of type I syndactyly were analysed for sex ratio and segregation pattern. Thirty-four of the pedigrees were from the published reports; 16 were collected in the State of Utah. Pedigrees with affected individuals showing webbing between the second and third toes are characterized by a sex ratio of affected individuals favouring males and a highly significant excess of affected sons of heterozygous fathers. A similar distorted segregation pattern is present in those pedigrees when the webbing involves the second and third toes and/or the third and fourth fingers, but not in those pedigrees when the webbing involves other digits. The reason for the distorted segregation pattern is unknown. Hypotheses include abnormal chromosome segregation and gametic selection.

Because of its usually conspicuous nature and frequently dominant mode of inheritance, the malformation, syndactyly, is a prime subject for family history studies. Pedigree and case studies of it are widespread in scientific and medical journals. The available information shows that syndactyly is characterized by phenotypic and genetic heterogeneity. Temtamy and McKusick (1969) have provided a useful system for classifying the various types of syndactyly. No data have been published giving the incidence of the various types in any population. From a study of nursery records on file in the Latter-Day Saints Hospital in Salt Lake City, Utah, Woolf and Woolf (1973) conclude that complete or partial webbing between the second and third toes is the most common kind of syndactyly. Individuals with this anomaly and/or webbing between the third and fourth fingers (complete or partial), with occasional involvement of other digits, are classified by Temtamy and McKusick (1969) as having type I syndactyly. Phenotypic and genetic heterogeneity also characterize type I syndactyly (Bell, 1953; Temtamy and McKusick, 1969; Woolf and Woolf, 1973). An autosomal allele appears to be segregating in some families that, in the heterozygote, causes webbing between the second and third toes with no involvement of the hands. This type of syndactyly, referred to as type Ia syndactyly by Woolf and Woolf (1973), seems to be genetically distinct from the condition found in other families where the webbing commonly involves the fingers. Representative pedigrees from Utah are given in Woolf and Woolf (1973).

In 1921, Schofield described a family with type Ia Received for publication 26 July 1976. syndactyly occurring in all the male descendants of an affected male over a span of four generations. No females were affected in this family. This unique pedigree is of historic interest because it was once used as one of the main examples of holandric inheritance. Though no other pedigree has been presented with type Ia syndactyly occurring exclusively in all male descendants of a single male (see Stern, 1957), a higher frequency of this type of syndactyly in males has been shown in other pedigrees (Gates, 1946; Penrose, 1946). In order to obtain further information on the sex ratio and segregation patterns for type Ia syndactyly, an analysis was made (a) of published pedigrees and (b) of those collected in the State of Utah by Woolf and Woolf (1973). For comparative purposes, an analysis was made of type I pedigrees ascertained in the same two ways with one or more of the members having webbing of the fingers.

\section{Procedure and results}

A search was made for those published pedigrees of type I syndactyly in which males and females were, in the main, clearly identified. Thirty-four pedigrees were thus obtained. Sixteen were added from the study of syndactyly in Utah (Woolf and Woolf, 1973), giving a total of 50. The pedigrees were classified as type Ia if all affected members had webbing between the second and third toes with no involvement of the fingers, and as type $\mathrm{Ib}$ if one or more of the affected members also had webbing between the third and fourth fingers. Twenty-four of the 50 pedigrees were classified as type Ia; the remainder (26) were classified as type Ib. 
Table 1 Number of affected individuals in pedigrees classified as type Ia and type Ib

$\begin{array}{lllll}\text { Pedigrees } & \begin{array}{l}\text { Affected } \\ \text { males }\end{array} & \begin{array}{l}\text { Affected } \\ \text { females }\end{array} & \begin{array}{l}\text { Affected } \\ \text { of } \\ \text { unknown } \\ \text { sex }\end{array} & \begin{array}{l}\text { Total } \\ \text { affected }\end{array} \\ & & & \end{array}$

\begin{tabular}{lrrrrr}
\cline { 2 - 6 } $\begin{array}{l}\text { Type Ia } \\
\text { syndactyly }\end{array}$ & 24 & 97 & 49 & 0 & 146 \\
\hline $\begin{array}{l}\text { Type Ib } \\
\text { syndactyly }\end{array}$ & & & & & \\
Group 1 & 18 & 68 & 51 & 1 & 120 \\
Group 2 & 5 & 40 & 37 & 0 & 77 \\
Group 3 & 3 & 8 & 7 & 0 & 15 \\
Totals & 26 & 116 & 95 & 1 & 212 \\
\hline
\end{tabular}

In the 24 pedigrees classified as type Ia there are 146 affected individuals; 97 are males and 49 are females (Table 1). Assuming an expected 1:1 sex ratio, the difference is highly significant $\left(\chi^{2}=15 \cdot 1\right.$; $\mathbf{P}<0.01$ ). The data do not support the hypothesis that the aberrant sex ratio is the result of lower penetrance in females than males. Such a hypothesis would predict that 'skips' in pedigrees would occur more frequently in females than males. In the 24 pedigrees under study, 9 individuals who were free of the trait, but who had an affected parent, produced at least 1 child with the trait. Eight of the 9 individuals were males; 1 was a female. These indi- viduals and all affected individuals in the pedigrees were classified as heterozygotes.

In the 24 pedigrees, heterozygous fathers produced 165 offspring, of which 90 are affected and 75 are normal (see Table 2). The difference is not significant $\left(\chi^{2}=1.2 ; 0.30>P>0.20\right)$. These heterozygous fathers produced 84 sons and 81 daughters. It is of interest that 63 of these sons but only 27 of the daughters are affected. This difference in the number of affected sons and daughters is highly significant $\left(\chi^{2}=13.6 ; \mathrm{P}<0.01\right)$. Among the progeny of heterozygous fathers, significantly more than $50 \%$ of the males $\left(\chi^{2}=20.0 ; \mathrm{P}<0.01\right)$, and significantly less than $50 \%$ of the females $\left(\chi^{2}=8.3 ; \mathrm{P}<0.01\right)$ are affected. Heterozygous fathers transmitted the allele to $66(78.6 \%)$ of their 84 sons (including 3 nonmanifesting skips) and to $28(34.6 \%)$ of their 81 daughters (including one skip).

The numbers of affected and normal offspring produced by heterozygous mothers do not deviate significantly from the values expected for an autosomally-determined heterozygous condition. Heterozygous mothers produced 26 affected and 32 normal offspring. This difference is not significant $\left(\chi^{2}=0.4\right.$; $0.70>\mathrm{P}>0.50$ ). Of 58 total offspring, 31 are male and 27 are female. Sixteen of the 31 sons and 10 of the 27 daughters are clinically affected. The difference between the number of affected sons and

Table 2 Normal and affected progeny of heterozygous parents in pedigrees classified as type Ia

\begin{tabular}{|c|c|c|c|c|c|c|c|c|}
\hline & \multicolumn{4}{|c|}{ Heterozygous fathers } & \multicolumn{4}{|c|}{ Heterozygous mothers } \\
\hline & \multicolumn{2}{|l|}{ Sons } & \multicolumn{2}{|c|}{ Daughters } & \multicolumn{2}{|l|}{ Sons } & \multicolumn{2}{|c|}{ Daughters } \\
\hline & Normal & Affected & Normal & Affected & Normal & Affected & Normal & Affected \\
\hline Castle (1923) & & & & & 4 & 0 & 3 & 3 \\
\hline Fantham (1924) & 0 & 10 & 0 & 4 & & & & \\
\hline Griffith (1910) & & & & & $\mathbf{0}$ & 1 & 0 & 1 \\
\hline Heston (1932) & 1 & 3 & 1 & 3 & 1 & $4(+1)$ & 5 & $\mathbf{0}$ \\
\hline Heston (1932) & 4 & $5(+1)$ & 9 & $0(+1)$ & $\mathbf{0}$ & 1 & $\mathbf{0}$ & 1 \\
\hline Hurlin (1920) & 1 & 3 & 2 & 1 & & & & \\
\hline Pipkin and Pipkin (1945) & 2 & 2 & 5 & 0 & & & & \\
\hline Pipkin and Pipkin (1945) & 0 & 3 & 4 & 0 & & & & \\
\hline Schofield (1921) & 0 & 13 & 11 & 0 & & & & \\
\hline Sommer (1916) & 0 & 8 & 0 & 6 & 2 & 0 & 1 & 0 \\
\hline Stiles and Hawkins (1946) & 0 & 0 & 2 & 3 & 3 & 0 & 0 & $\mathbf{0}$ \\
\hline Straus (1925) & 0 & 4 & 0 & 1 & & & & \\
\hline Straus (1925) & & & & & 1 & 2 & 0 & 1 \\
\hline Straus (1925) & 0 & 0 & 3 & 0 & & & & \\
\hline Straus (1925) & $\mathbf{0}$ & $\mathbf{0}$ & 0 & 1 & & & & \\
\hline Thomsen (1927) & & & & & 0 & 0 & 0 & 1 \\
\hline Wölfflin (1925) & 2 & 0 & 1 & 1 & $\mathbf{0}$ & 3 & 2 & 0 \\
\hline Woolf and Woolf (1973) & 5 & $4(+2)$ & 6 & 2 & 1 & 2 & 3 & 2 \\
\hline Woolf and Woolf (1973) & 0 & 1 & 2 & 1 & $\mathbf{0}$ & 2 & 0 & 1 \\
\hline Woolf (unpublished) & & & & & 2 & 1 & 3 & 0 \\
\hline Woolf (unpublished) & 1 & 3 & 4 & $\mathbf{0}$ & & & & \\
\hline Woolf (unpublished) & 0 & 2 & 0 & 2 & & & & \\
\hline Woolf (unpublished) & 1 & 1 & 1 & $\mathbf{0}$ & & & & \\
\hline Wright (1922) & 1 & 1 & 2 & 3 & & & & \\
\hline Totals & 18 & $63(+3)$ & 53 & $27(+1)$ & 14 & $16(+1)$ & 17 & 10 \\
\hline
\end{tabular}

Figures in parentheses in Table 2-4 refer to unaffected transmitters (skips) 
Table 3 Normal and affected progeny of heterozygous parents in pedigrees classified as type Ib

\begin{tabular}{|c|c|c|c|c|c|c|c|c|}
\hline & \multicolumn{4}{|c|}{ Heterozygous fathers } & \multicolumn{4}{|c|}{ Heterozygous mothers } \\
\hline & \multicolumn{2}{|l|}{ Sons } & \multicolumn{2}{|c|}{ Daughters } & \multicolumn{2}{|l|}{ Sons } & \multicolumn{2}{|c|}{ Daughters } \\
\hline & Normal & Affected & Normal & Affected & Normal & Affected & Normal & Affected \\
\hline $\begin{array}{l}\text { Group } 1 \\
\text { Bell (1931) } \\
\text { Kirchmair (1936) } \\
\text { Montagu (1953) } \\
\text { Roskoschny (1918) } \\
\text { Thomsen (1927) } \\
\text { Temtamy No. } 1 \text { (1966) } \\
\text { Temtamy No. } 3 \text { (1966) } \\
\text { Wolff (1921) } \\
\text { Woolf (unpublished) } \\
\text { Woolf (unpublished) } \\
\text { Woolf (unpublished) } \\
\text { Woolf (unpublished) } \\
\text { Woolf (unpublished) } \\
\text { Woolf and Woolf (1973) } \\
\text { Woolf (unpublished) } \\
\text { Woolf (unpublished) } \\
\text { Woolf and Woolf (1973) } \\
\text { Woolf (unpublished) }\end{array}$ & $\begin{array}{l}3 \\
3 \\
0 \\
2 \\
3 \\
\\
2 \\
0 \\
0 \\
3 \\
1 \\
0 \\
0 \\
1\end{array}$ & $\begin{array}{l}4 \\
2 \\
1 \\
2 \\
6(+1) \\
2 \\
9 \\
2 \\
0 \\
1 \\
4 \\
0 \\
0\end{array}$ & $\begin{array}{l}2 \\
3 \\
6 \\
1 \\
5 \\
\\
0 \\
6 \\
1 \\
3 \\
0 \\
0 \\
0 \\
1\end{array}$ & $\begin{array}{l}3 \\
2 \\
5(+1) \\
0 \\
3 \\
0 \\
5 \\
0(+1) \\
0 \\
0 \\
2 \\
1 \\
0(+1)\end{array}$ & $\begin{array}{l}5 \\
0 \\
4 \\
2 \\
0 \\
8 \\
0 \\
4 \\
8 \\
\\
3+ \\
0 \\
1 \\
4 \\
0 \\
1 \\
0 \\
\end{array}$ & $\begin{array}{l}2 \\
3 \\
2 \\
3 \\
1 \\
1 \\
1 \\
0(+1) \\
1 \\
1 \\
1 \\
3 \\
1 \\
2 \\
0 \\
0\end{array}$ & $\begin{array}{l}5 \\
0 \\
1 \\
1 \\
1 \\
0 \\
4 \\
4 \\
5 \\
6 \\
\\
1 \\
1 \\
1 \\
5 \\
2 \\
3 \\
1\end{array}$ & $\begin{array}{l}3 \\
2 \\
1(+1) \\
0 \\
1 \\
2(+1 \\
0 \\
2(+1) \\
1 \\
0 \\
0 \\
1 \\
1 \\
0(+1) \\
1 \\
1\end{array}$ \\
\hline $\begin{array}{l}\text { Subtotals } \\
\text { Group } 2 \\
\text { Berigny (1863) } \\
\text { Hannebelle (1896) } \\
\text { Lueken (1938) } \\
\text { Malhotra and Rife (1963) } \\
\text { Temtamy No. } 2 \text { (1966) }\end{array}$ & $\begin{array}{r}18 \\
4 \\
0 \\
15 \\
8 \\
3\end{array}$ & $\begin{array}{l}34(+1) \\
2 \\
2 \\
6 \\
5(+1) \\
7\end{array}$ & $\begin{array}{r}29 \\
1 \\
0 \\
9 \\
7 \\
2\end{array}$ & $\begin{array}{r}21(+3) \\
1 \\
0 \\
14 \\
2 \\
2\end{array}$ & $\begin{array}{r}40 \\
2 \\
12 \\
1\end{array}$ & $\begin{array}{l}22(+1) \\
1(+1) \\
12 \\
2\end{array}$ & $\begin{array}{r}40 \\
2 \\
18 \\
0\end{array}$ & $\begin{array}{l}16(+4) \\
2(+2) \\
15 \\
0\end{array}$ \\
\hline $\begin{array}{l}\text { Subtotals } \\
\text { Group } 3 \\
\text { Barsky (1951) } \\
\text { Davis and German (1930) } \\
\text { Guyer (1916) } \\
\end{array}$ & $\begin{array}{l}30 \\
7 \\
0 \\
2\end{array}$ & $\begin{array}{l}22(+1) \\
1(+2) \\
1 \\
0\end{array}$ & $\begin{array}{r}19 \\
7 \\
1 \\
1\end{array}$ & $\begin{array}{l}19 \\
2 \\
0 \\
0(+1)\end{array}$ & $\begin{array}{l}15 \\
1 \\
5 \\
0\end{array}$ & $\begin{array}{l}15(+1) \\
1 \\
1 \\
2\end{array}$ & $\begin{array}{l}20 \\
1 \\
4 \\
0\end{array}$ & $\begin{array}{l}17(+2) \\
1 \\
1 \\
0(+1)\end{array}$ \\
\hline Subtotals & 9 & $2(+2)$ & 9 & $2(+1)$ & 6 & 4 & 5 & $2(+1)$ \\
\hline Totals & 57 & $58(+4)$ & 57 & $42(+4)$ & 61 & $41(+2)$ & 65 & $35(+7)$ \\
\hline
\end{tabular}

affected daughters is not significant $\left(\chi^{2}=1 \cdot 0\right.$; $0.50>P>0.30$ ).

The distorted sex ratio and segregation patterns observed for type Ia syndactyly are not present in the 26 pedigrees collectively classified as type Ib (see Tables 1 and 3). There are 212 affected individuals in these pedigrees; 116 are males, 95 are females, and the sex of 1 is unknown. The difference between the number of males and females in this affected group is not significant $\left(\chi^{2}=1.9 ; 0.20>P>0 \cdot 10\right)$. In the 26 pedigrees there are 17 skipped offspring of 11 heterozygous parents, 11 female and 6 male.

The published material suggests, however, that type Ib syndactyly is genetically heterogeneous. In some families the webbing in affected individuals is restricted to the third and fourth fingers and second and third toes; it may include other digits in affected individuals in other families. For example, in the Lueken pedigree (1938), the webbing in some of the affected individuals involves the second to the fifth fingers and the second to the fourth toes. In order to determine if any major subtype of type Ib syndactyly might show distorted sex ratios and segregation patterns, the 26 pedigreees were divided into 3 groups. The first group includes 18 pedigrees with individuals in whom the webbing is restricted to the second and third toes and third and fourth fingers. The second group includes 5 pedigrees with individuals having more extensive or unique digit involvement. Three pedigrees were placed in a third group because the exact location and extent of the webbing in the affected individuals could not be determined from the published information. The sex ratio of affected individuals does not deviate significantly from a $1: 1$ ratio in any of these groups; however, there is a trend in that direction in group 1. Furthermore, even though all data in groups 2 and 3 are compatible with the hypothesis of autosomal inheritance with reduced penetrance in both males and females, the same is not true for the data group 1. In that group, there is a distorted segregation pattern as in type Ia syndactyly. Significantly more than $50 \%$ of the sons of heterozygous fathers have syndactyly $\left(\chi^{2}=4 \cdot 3\right.$; $0.05>\mathrm{P}>0.01$ ). 
Table 4 Normal and affected progeny of heterozygous parents in pedigrees classified as type Ia and type Ib group 1

\begin{tabular}{|c|c|c|c|c|c|c|c|c|}
\hline & \multicolumn{4}{|c|}{ Heterozygous fathers } & \multicolumn{4}{|c|}{ Heterozygous mothers } \\
\hline & \multicolumn{2}{|l|}{ Sons } & \multicolumn{2}{|c|}{ Daughters } & \multicolumn{2}{|l|}{ Sons } & \multicolumn{2}{|c|}{ Daughters } \\
\hline & Normal & Affected & Normal & Affected & Normal & Affected & Normal & Affected \\
\hline \multirow{2}{*}{$\begin{array}{l}\text { Type Ia } \\
\text { Type Ib } \\
\text { Group 1 }\end{array}$} & 18 & $63(+3)$ & 53 & $27(+1)$ & 14 & $16(+1)$ & 17 & 10 \\
\hline & 18 & $34(+1)$ & 29 & $21(+3)$ & 40 & $22(+1)$ & 40 & $16(+4)$ \\
\hline Totals & 36 & $97(+4)$ & 82 & $48(+4)$ & 54 & $38(+2)$ & 57 & $26(+4)$ \\
\hline
\end{tabular}

\section{Discussion}

This study shows a distorted segregation pattern for those types of syndactyly that are characterized by webbing between the second and third toes and the third and fourth fingers. Heterozygous fathers produce more affected sons than normal sons, a result not expected on the basis of autosomal dominant inheritance. The excess at least partially accounts for the significantly distorted sex ratio of affected individuals in favour of males for type Ia syndactyly and for a trend in that direction of type Ib syndactyly. An unresolved problem is whether the latter is genetically different from the former. The existence of families with the webbing restricted to the toes in all affected members and the high prevalence of individuals with finger involvement in other families suggests genetic heterogeneity. A complicating fact, however, is the observation that in some families an occasional individual will occur with webbing of the fingers even though in all other affected individuals in the family the webbing is restricted to the second and third toes. Such occurrences count as defects of a classification system in which type Ia syndactyly is regarded as a distinct genetic entity, but they are consistent with a variant of that classification in which type Ia families are a group of distinct entities, some having one particular abnormal allele, some another. The different alleles may or may not be all at the same locus.

Conclusions based on pedigrees collected from the published reports are fraught with uncertainties. For example, the pedigree that shows the most distorted segregation pattern was reported by Schofield (1921). The investigations of Stern (1957) lead to the conclusion that the accuracy of this pedigree is still 'undecided'. However, omitting this pedigree from the analysis still yields data suggesting that for type Ia syndactyly, heterozygous fathers produce significantly more affected sons than affected daughters $\left(\chi^{2}=6.3 ; 0.05>P>0.01\right)$ and more affected sons than normal sons $\left(\chi^{2}=11.0 ; P<0.01\right)$. Even though the Schofield pedigree may not be completely accurate, there seems to be a genuinely distorted sex ratio of affected individuals in favour of males and at least a certain amount of concordance between fathers and sons. Confidence can be placed in the pedigrees of Woolf and Woolf (1973) and in these pedigrees heterozygous fathers transmittted the trait to 7 of 9 sons and to 2 of 9 daughters.

In spite of the possible inaccuracies and biases resulting from analysing pedigrees from the reports, all available data for type Ia and type Ib group 1 syndactyly suggest that in the progeny of heterozygous males there is an excess of affected sons and that this does not occur in the progeny of heterozygous females. It also does not occur for type I syndactyly when digits other than the second and third toes and the third and fourth fingers may also be webbed, suggesting that different genetic mechanisms account for these conditions. In Table 4 the data are combined for type Ia syndactyly and the cases referred to here as type Ib group 1 syndactyly. The excess of affected sons of affected fathers is striking even after allowance is made for reduced penetrance. Reduced penetrance, however, may explain the difference between the numbers of affected and normal progeny produced by heterozygous mothers. One model to explain the data would be a type of segregation distortion where at the first meiotic division, the autosome with the allele for syndactyly tends to go to the same pole as the $\mathrm{Y}$ chromosome. Another model would be gametic selection whereby two classes of sperm cells have an increased probability of fertilizing the egg; one class possessing the normal allele and an $\mathrm{X}$ chromosome, the other the abnormal allele and a Y chromosome. Any hypothesis should preferably provide an explanation (even if it be simply one of chance) for the observed normal sex ratio of total males and total females born to heterozygous fathers.

The results of this study suggest that other types of syndactyly should be investigated for segregation distortion. Evidence for a disturbed segregation has already been noted for ectrodactyly (lobster claw), which represents an extreme form of webbing. As early as 1908 , Pearson studied a family with this disorder and suggested that matings of normals with 
abnormals produced an excess of offspring who were abnormal. From a review of the published reports, Stevenson and Jennings (1960) found the following disturbed ratio among the progeny of affected males: affected sons, 93; unaffected sons, 58; affected daughters, 57; unaffected daughters, 59 . The excess of affected sons was not observed in the offspring of affected females. They state that if the finding is not the result of chance, the most likely explanation is a type of gametic selection whereby the sperm which carries both the autosomal ectrodactyly gene and the $\mathrm{Y}$ chromosome is favoured at fertilization.

An abnormal segregation pattern is also known for Alport's syndrome (Graham, 1960; Shaw and Glover, 1961). By analysing pooled data from 35 pedigrees, MacNeill and Shaw (1973) conclude there is an excess of heterozygotes at fertilization and propose that the only mechanism known at present to account for it is non-random segregation. They favour the Shaw and Glover (1961) hypothesis which states that during oogenesis the chromosome bearing the mutant gene tends to migrate to the oocyte rather than to the polar body and during spermatogenesis it tends to migrate to the same pole as the X chromosome.

Shaw et al. (1960) have shown that in sibships where the dominant gene for congenital aniridia is segregating, a 38:62 ratio of affected to normal children is present instead of the expected Mendelian ratio of 50:50. They showed that the deviation was probably not a function of decreased penetrance, sex of the parent, or infant mortality. Possible explanations include some type of abnormal chromosome segregation in males and females, differential gametic survival, or decreased viability of zygotes or very young embryos with the aniridia gene.

Because they represent exceptions to Mendelian inheritance, traits in man showing disturbed ratios present special situations for genetic counselling. The disturbed ratios should be considered in determining the risk values used in genetic counselling. Even though cases of ectrodactyly, Alport's syndrome, aniridia, and extreme cases of webbing are part of a genetic counsellor's expected load, type Ia syndactyly, because it is a minor anomaly, is usually brought to the attention of a counsellor or human geneticist only out of curiosity. Its nondetrimental nature is one reason for the paucity of published pedigrees. However, the disturbances of sex- and segregation-ratios associated with this trait suggest that it should be the subject of extensive pedigree studies in different populations.

Of interest is the similarity of the disturbed segregation ratios for type Ia syndactyly, type Ib group 1 syndactyly, and ectrodactyly. In each case, it occurs only in the progeny of affected males. Addi- tional studies may show that the same biological phenomenon is working for each of these digital ray disorders.

\section{References}

Barsky, A. J. (1951). Congenital anomalies of the hand. Journal of Bone and Joint Surgery, 33-a (1), 35-64.

Bell, J. (1931). Three further cases of hereditary digital anomaly seen in the out-patient department of Great Ormond Street Hospital for Sick Children. Annals of Eugenics, 4, 233-237.

Bell, J. (1953). On syndactyly and its association with polydactyly. Treasury of Human Inheritance, 5, 33-43.

Berigny (1863). Cited by Bell (1953).

Castle, W. E. (1923). Further data on webbed toes. Journal of Heredity, 14, 209-210.

Davis, J. S., and German, W. J. (1930). Syndactylism (coherence of fingers and toes). Archives of Surgery, 21, 32-75.

Fantham, H. B. (1924). Heredity in man: its importance both biologically and educationally. South African Journal of Science, 21, 428-527.

Gates, R. R. (1946). Human Genetics, Vol. 1, pp. 385-469. Macmillan, New York.

Graham, J. B. (1960). Chronic hereditary nephritis not shown to be partially sex-linked. American Journal of Human Genetics, 12, 382-384.

Griffith, F. (1910). Case of congenital fusion of toes, with notes on previous generations. Medical Record, 78, 67 .

Guyer, M. F. (1916). Being Well-Born, p. 121. Bobbs Merrill. Hannebelle, P. (1896). Cited by Bell (1953).

Heston, W. E. (1932). Inheritance of 'webbed toes'. Journal of Heredity, 23, 379-381.

Hurlin, R. G. (1920). A case of inherited syndactyly in man. Journal of Heredity, 11, 334-335.

Kirchmair, H. (1936). Ein Syndaktylie-stammbaum. Münchener medizinische Wochenschrift, 83, 605-606.

Lueken, K. G. (1938). Über eine familie mit syndaktylie. Zeitschrift für menschliche Vererbungs-und Konstitutionslehre, 22, 152-159.

MacNeill, E., and Shaw, R. F. (1973). Segregation ratios in Alport's syndrome. Journal of Medical Genetics, 10, 23-26.

Malhotra, K. C., and Rife, D. C. (1963). Syndactyly and clinodactyly within an Indian kindred. Journal of Heredity, 54, 219-220.

Montagu, M. F. (1953). A pedigree of syndactylism of the middle and ring fingers. American Journal of Human Genetics, 5, 70-72.

Pearson, K. (1908). On the inheritance of the deformity known as split-foot or lobster claw. Biometrika, 6, 69-79.

Penrose, L. S. (1946). Inheritance of zygodactyly. Journal of Heredity, 37, 285-287.

Pipkin, A. C., and Pipkin, S. B. (1945). Two new pedigrees of zygodactyly. Journal of Heredity, 36, 313-316.

Roskoschny, F. (1918). Symmetrische Syndaktylie beider Hände und Füsse. Deutsche medizinische Wochenschrift, 44, 350 .

Schofield, R. (1921). Inheritance of webbed toes. Journal of Heredity, 12, 400-401.

Shaw, M. W., Falls, H. F., and Neel, J. V. (1960). Congenital aniridia. American Journal of Human Genetics, 12, 389-415.

Shaw, R. F., and Glover, R. A. (1961). Abnormal segregation in hereditary renal diseases with deafness. American Journal of Human Genetics, 13, 89-97.

Sommer (1916). Zur forensischen Beurteilung der Erblichkeit von morphologischen Abnormitäten und der Papillarlinien der Finger. Archiv für Kriminologie, 66, 161-174. 
Stern, C. (1957). The problem of complete Y-linkage in man. American Journal of Human Genetics, 9, 147-166.

Stevenson, A. C., and Jennings, L. M. (1960). Ectrodactylyevidence in favour of a disturbed segregation in the offspring of affected males. Annals of Human Genetics, 24, 8996.

Stiles, K. A., and Hawkins, D. A. (1946). The inheritance of zygodactyly. Journal of Heredity, 37, 16-18.

Straus, W. L. (1925). The nature and inheritance of webbed toes in man. Journal of Morphology, 41, 427-439.

Temtamy, S. A. (1966). Genetic factors in hand malformations. Dissertation for Doctor of Philosophy at Johns Hopkins University, Baltimore, Maryland.

Temtamy, S., and McKusick, V. A. (1969). Synopsis of hand malformations with particular emphasis on genetic factors.
Birth Defects Original Article Series, 5, No. 3, 125-184. National Foundation-March of Dimes, New York.

Thomsen, O. (1927). Einige Eigentümlichkeiten der erblichen Poly-und Syndaktylie bei Menschen. Acta Medica Scandinavica, 65, 609-644.

Wolff, F. (1921). Ein Fall Dominanter Vererbung von Syndaktylie. Archiv für Rassen und Gesellschafts Biologie, 13 74-75.

Wölfflin, E. (1925). Ueber einem Stammbaum von Syndaktylie. Archiv für Rassen und Gesellschafts Biologie, 17, 412413.

Woolf, C. M., and Woolf, R. M. (1973). A genetic study of syndactyly in Utah. Social Biology, 20, 335-346.

Wright, S. (1922). Another pedigree of webbed toes. Journal of Heredity, 13, 118. 